\title{
Online Mediatization of the Identity of the Writers During the Pandemic Corina Ozon
}

Faculty of Journalism and Communication Sciences, University of Bucharest, Romania

\author{
Онлайн медиатизация на самоличността на писателите по време на пандемията \\ Корина Озон \\ Факултет по журналистика и комуникационни науки, Букурещки университет, Румъния
}

\section{Author Note}

Corina Ozon (iD https://orcid.org/0000-0001-7068-5568

The author declared no potential conflicts of interest concerning the authorship and publication of this article.

The author's corresponding address is Faculty of Journalism and Communication Sciences, University of Bucharest, 1-3 Iuliu Maniu, Building A, 6th Floor, Bucharest, 061071. Email: corinaozon@gmail.com; elena-corina.ozon@drd.unibuc.ro

\section{Бележки за автора}

Корина Озон (iD https://orcid.org/0000-0001-7068-5568

Авторът декларира, че няма потенциален конфликт на интереси с авторството и публикуването на тази статия.

Адрес за кореспонденция с автора: Faculty of Journalism and Communication Sciences, University of Bucharest, 1-3 Iuliu Maniu, Building A, 6th Floor, Bucharest, 061071. Email: corinaozon@gmail.com; elena-corina.ozon@drd.unibuc.ro 


\begin{abstract}
Self-exposure has become a mode of communication on which the functioning of social networks and blogs is based. Internet users create content in the digital environment, built on habits acquired in the old media. Remixability and mobility make possible new forms of mediation and self-production in the process of mediatization. During the research on the self-exposure of Romanian writers in the online environment, the pandemic represented the opportunity to investigate the behavioral changes in the conditions of prohibiting face-to-face events (including cultural ones). Starting from the hypothesis that, given the quarantine period and the prohibition of events, the only sources of information are traditional media, especially television. Through mediatization, the authors apply strategies to keep their visibility online to promote their books through self-exposure and emergence of identities. The research used autoethnography, based on the writer's experience, to track the emergence of identities and the types of narration used in the posts and their multimodality. Monitoring for data collection was performed on a private site like a diary/blog and processed with empirical tools. We noticed that the writers had exposed themselves online by mediatized identities, and the narratives had diversified during that period; identities and posts are mediatized around the news provided by the media. Researched periods: 23-29 March and 13-20 April 2020. Total posts: 224. This study could be apart from a bigger social image of life during the pandemic when online activity had intensified.
\end{abstract}

Keywords: identity, writer, social media, mediatization, pandemic, self-exposure

\title{
Резюме
}

Самопредлагането се превърна в начин на комуникация, на който се основава функционирането на социалните медии и блоговете. Потребителите на интернет създават съдържание в цифрова среда, изградено върху навици, придобити в старите медии. Ремиксабилността и мобилността правят възможни нови форми на медиация и самопроизводство в процеса на медиатизация. По време на изследване на самопредлагането на десет румънски писатели в онлайн среда възникна пандемията. Възникна и друг контекст за изследване на поведенческите промени в условия на забрана на събития, включително културни. Изхождайки от хипотезата, че предвид карантинния период и забраната за събития, единствените източници на информация са тези на традиционните медии, особено телевизията, чрез медиатизация авторите прилагат онлайн 
стратегии за запазване на видимостта си, за да популяризират своите книги чрез самопредлагане. Изследването използва автоетнография, основана на писателския опит, за да проследи появата на писателската идентичност и на видовете разказ, използвани в публикациите им, както и тяхната мултимодалност. Мониторингът на събираните данни е представен на частен сайт под формата на дневник/блог и се обработва с емпирични инструменти. Забелязахме, че авторите се представят онлайн чрез медиирани идентичности и разказите са се разнообразили през този период, самоличността и публикациите се медиирали около новините, предоставени от медиите. Изследван периоди: 23-29 март и 13-20 април 2020 г. Общо публикации - 224. Това проучване би могло да бъде част от по-голям социален образ на живота по време на пандемия, когато онлайн активността е интензифицирана.

Ключови думи: идентичност, писател, социални медии, медиатизация, пандемия, самопрезентиране 


\section{Online Mediatization of the Identity of the Writers During the Pandemic The identity as a product in the online environment}

The starting of the study of a group of ten contemporary Romanian writers aimed to analyze how they use self-exposure to promote books. Social networks work through selfexposure, but users' behavior is different according to their goals. We started our endeavor by monitoring their activity on Facebook starting with August 2019, taking into account important book events and the periods before and after them to see how they had built their identities to keep their readerships and expand them. The monitoring continued with the pandemic's onset, which brought a series of restrictions that mainly aimed at closing public events; the most affected were cultural events. Thus, online exposure has become a challenge for writers, especially since the physical bookstores have not been opened, the books being available in virtual bookstores. This is the period covered by the article.

The identity concept has undergone various transformations since psychologists' statement, then the emergence of television setting up the industry of celebrity and celebrification, anonymous people becoming known in public. With the phenomenon of "celebrization" and "democratization" (Turner, 2006), the identity has become a support for product marketing, being in its turn a product rating based on the success rate through what we call "mobility." One of the celebrity indicators is mobility, the way a star can migrate from one space to another and maintain his/her performance-based notoriety indices.

"Migration is thus a twofold process that captures the mobility and convertibility of celebrity. Migration within a certain field occurs when celebrities diversify their activities in the field in which they have established their celebrity status" (Driessens, 2013, p. 648).

The internet and social networks have led to the "individualization" of identity. Individualization is specific to Western society and is associated with personalization: "Personalization goes hand in hand with individualization." (Driessens, 2013, p. 651).

Social networks use classic communication and cultural tools to create new forms of interaction through users' contribution in various fields that create content, making the information reversible on the internet. 
"We link this remixability with the reversibility of the roles between authors/audiences that characterize this Internet age called read/write or user based in Anglo-Saxon literature, remixability and reversibility, the participant in an expressive paradigm in which the Internet is both an observer and an architect" (Allard, 2007, p. 21).

The reversibility and remixability occur in the case of writers because they are architects and subjects of their actions on the internet, and from the interaction with readers, a new form of content is created, the activity on social networks presenting itself as teamwork, a kind of "dramaturgical cooperation" in Goffman's vision (Bouvier, 2012, p. 41).

The "imaginary territories" have favored the emergence of identities in the virtual environment and transferred Goffman's dramatic behavior. Identities manifest intentionally but also reactively during interaction with others (Goffman, 1967).

Users' self-exposure on social media has been driven by blogs and by disclosure and Big Brother type of shows promoted by traditional media. By transgressing taboo subjects and neutralizing them in the public space, self-disclosure has become a pattern for the celebrity industry. Success stories or intimate, traumatic topics have helped to encourage self-expression. In the online environment, storytelling has helped to create communities, their members feeling connected to each other through stories. "On Internet social networks, self-exposure is, therefore, the main relational technique" (Cardon, 2006, p 142).

Beyond the economic benefits (we refer to advertising in the broadcast space), the audience creates a personal ranking of the stars created in the above-listed contexts, and this celebrization has contributed even more to the development of the spectator's identity, not only by involuntary or voluntary mimicry of certain attitudes but also in social interaction. The motivation through the "Do it yourself" (DIY) messages conveyed by the emergence of this type of heroes have contributed to the creation of the "culture of self-disclosure" (Miller, Shepperd, 2004, p. 5) and encouragement of self-expression, a process called "democratization" (Turner, 2006, p. 157), which was made possible by the access of the "ordinary" to the media content.

This celebrization has been achieved over time, experiencing the phenomenon of Hollywood stars, but in what follows, we will refer to the celebrization in the traditional media space and then in social networks. 
"The explosion of reality TV, confessional talk formats, docu-soaps, and so-called realitybased game shows has significantly enhanced television's demand for ordinary people desiring celebrification" (Turner, 2006, p 155).

The celebrity was transferred online in the form of influencers. All users of social networks create content, thus maintaining the platform's functioning, but the influencers create marketed content, presenting as a guarantee a large number of followers and the quantified impact of the posts. In other words, they are product identities that, in their turn, are marketed to become support for commercials. The individualization made by the virtual environment made possible this transfer of celebrity to online, and the fan communities were also virtualized. The classic model of fan clubs was on collective identity, the members of the fan communities have their own identity on the internet; moreover, Facebook recently introduced the "Active fan" label to users who are vocal in comments. The writers who are the subject of this study have fans and pages that bring communities together through regular interaction. Some of the writers' activity is very intense. Others are not so present online, but they have media activities such as radio and TV shows or movies generated by Facebook, YouTube channels, and blogs.

Some of the writers are influencers through many followers and reactions to posts, promoting their turn books written by other authors in advertising, thus becoming produced identities. Facebook has also introduced the "Author" tag for each user who creates content.

\section{Identity mediatization}

\section{Self-mediatization - we will take into consideration self-mediatization, which involved self- exposure}

Since the pandemic declaration, we had followed the activity on Facebook of ten Romanian writers during the two months. There has been an emergence of identities in the first period since the beginning of the March 2020 lockdown, closely linked to emotions: the identity of a psychologist, a child, a parent, etc. As the narratives diversified, the identities became mediatized; more precisely, they were built around the information disseminated by the traditional media and the virtual environment. In the absence of other sources and public events, and institutionalization of identity and self-mediatization has occurred because of each user, and here we refer to writers, transmitted through its posts the reality from its perspective. We mention a few topics: the debate on celebrating Easter in quarantine, on wearing a mask, on the existence 
of the virus, etc. The influencer writers have propagated their communities mediatized content passed through a momentary identity's filter to whom we will refer in the following.

"The new media have become a space for 'self-production of society', where a struggle for society's making is taking place" (Hidri, Smati, 2013). Social networks operate through selfexposure, which leads to the creation of content by users. From this self-exploration, an emergence of the contents from the social media flow or the phenomenon called "The New Media Romanticism” occurs.

A feature of social networks is that users become actors and performers because the standardization of rules and tools has led to the actors' online performance, who become agents of their actions, being content creators. The form of an invitation to socialization is a challenge of self-expression and self-exposure. The writers, who are the subject of our area of interest, use it as a communication strategy to promote their books.

The artificial construction that is the social network has a global character because users are from all over the world, but unlike mainstream media, the users are not only spectators but also performers who use a common language in the communication on virtual platforms, called "mass self-communication" (Castells, 2009). What Fiske said about television is that it forms a "texture that fills the gaps in everyday life" through its programs (Fiske, 1989, p 156); in social media, the content created by users through self-expression leads to interactions and implicitly to communication in which each becomes a performer of its post.

The identities are born from these narratives that end up being competitive, doubled by comments, reactions that contain arguments or disagreements. The threats, i.e., the discussions arising from a comment, develop due to a competitive spirit and the power relations between the discussion members.

The phenomenon of democratization has also occurred online, where ordinary people become known, not through achievements in a particular activity/field, but through the reputation of being vocal online, that "transition from achieved celebrity to assigned celebrity" (Holmes, 2005, p. 646).

This has been easier to achieve on the internet due to the democratization of technology. The traditional media has gone digital, on websites and social media, transferring communities from the former forums and offering new communication tools. Thus, it established an operating 
framework, usually for the members participating in the discussions, who, in their turn, transferred them to their own social media profiles.

“.... the term «mediatization» refers to a social change process in which media have become increasingly influential in and deeply integrated into different spheres of society" (Strömbäck, 2014, p. 4).

Mediatization has known several definitions and approaches (Esser, Strömbäck, 2014, p. 4). The media coverage involves self-production using virtual tools, so it is about a process of individualization. Esser and Strömbäck (2014) talk about four media transformation processes: extension, replacement, merger, and accommodation, very interesting in the junction's history with new media. Thus, through the internet, people can communicate regardless of space and time and without meeting. And in the case of the media, there is the advantage of archiving content accessible over time. Social media also uses this memory storage application so that users can find various past posts.

With the gradual introduction of various tools, social media actors have expanded their skills using them for personal purposes. This is the case of those who have become famous in social media, the influencers who use media technology through their talents to commercialize and achieve self-mediatization.

The self-mediatization also contains the intention of reflexivity, self-exposure, which requires creativity and creates competition. The exercise gained in user interaction on messenger, forums, and discussions in the blogosphere have been refined on social networks. The permissiveness to comment or accept comments draws "a threshold of modesty" (Granjon, Denouël, 2010, p. 40), more precisely the limits within which a discussion can occur between members of a group reacting to a post. The posts are self-exposures, even by expressing personal thoughts. Transgression leads to the public's education by imposing limits by the author of the position that allows how far self-disclosure can go, a mechanism called "the new dialectic of modesty/impudence“(p. 40).

\section{The "metamorphosis" of the identities in online}

Goffman's (2007) dramaturgical vision of interpersonal relationships is also transferred to the virtual environment. The communities are established in an "affective" way, and each individual joins or leaves the community according to the ideas it resonates with or not. "I define 
affective publics as networked public formations that are mobilized and connected or disconnected through expressions of sentiment" (Papacharissi, 2014, p. 125). The performers establishing communities practice various strategies to capture attention and increase the audience.

Contemporary writers belong to the intellectual category that uses social networks and other platforms to promote books through self-exposure. They act through agentivity, i.e., they are the agents of their actions, building their image through a practice of identity metamorphoses. Specifically, writers intentionally create relational contexts to promote products, using their image, in the sense of reputation and emergence of identity.

"Goffman draws upon Park's insight that the definitional origin of 'person' is a mask, and what is constructed via Facebook but equally through Twitter is a construction of character for a kind of ritual of the performance of the self' (Marshall, 2010, p. 40).

Marshall (2010) identified three levels of public self online: the first, in which the official version of the celebrity is presented; the second level is that of the public presentation of the public self, the one in which the star interacts with the community; the third level is of the transgressive intimate self, i.e., the moment when a certain value produces the growth of the self.

"The Facebook community can be conceptualized as a team performance, achieving Goffman's (1959, p. 83) 'dramaturgical cooperation' in confirming each other's performances of self”' (Bouvier, 2012, p. 41).

This creation of one's own identity invites a self-assessment concerning others and the power of mobility offered by technology. Other networks like Instagram, Linked In, and Twitter use multimodal forms of identity expression.

The analysis of everyday life's spectacle, which Goffman (2007) speaks of, demonstrates that the social actors perform an identity they want in public, in difficult situations. Stories help to discover and form an identity, for example, biographical stories. Through these identities, communities are established, communities that recognize themselves in stories or want to project their own identity according to the narrated model or talk about the mythical behavior stated by Mircea Eliade (1978).

The public behavior of political actors, for example, has been imposed by the media: "The mediatization literature is based on the idea that media influence politics, and claims that political 
actors need to adapt to the media and its logic" (Strömbäck, 2014, p. 208). Before taking action, the politicians think about how they will manage it in the media, and their behavior and activities will follow a certain model imposed by the media, that is why we can talk about mediatization in this case.

The fact that certain changes have been discussed over time in mediatization, changes such as the transition to print or digital, "old media," and "new media," proves the historical nature of mediatization. Under their influence, we can talk about the stage of institutionalized media coverage by the old media and self-mediatization built by individualization allowed by the internet, more precisely the social media (Deacon, Stanyer, 2014, p. 1036).

Each stage came with new models and tools that influenced media actors and consumers' behaviors, and the "diachronic approach" of mediatization is necessary to follow up the changes and transformations in the long run (p. 1038).

Chouliaraki speaks of self-mediatization as a "new field of democratization," precisely because technologies allow ordinary public visibility (2010, p. 227). As it happened with the phenomenon of celebrization in traditional media:

"Celebrification, in contrast, comprises the changes at the individual level, or, more precisely, the process by which ordinary people or public figures are transformed into celebrities - e.g., film stars, academy stars, celebrity politicians or so-called socialites like Paris Hilton" (Driessens, 2013, p. 643)

In the virtual environment, we can also talk about remixability. In creating a distinct identity, the information transmitted and the way it is communicated are essential. The presence in the online environment has also brought a change of perception of the public and private space so that "personal themes turn into public subjects" (Cardon, 2011, p. 6). The same transgression of certain limits applies.

The diachronic approach allows us to see the remixability of this product. The collaboration of representatives from several fields has led to the emergence of new forms in culture by remixing, the elements of one culture were borrowed from another culture and then gave rise to another form of culture. For example, the printing industry and the literature, by printing short quotes on clothing and accessories (pop art), or the remixing in music became very popular. 
Social networks use the classic tools from communication and culture to achieve new forms of interaction through the contribution of users in various fields that create content, which makes the information reversible on the internet.

"We link this remixability with the reversibility of the roles between authors/audiences that characterize this age of the Internet also called read/write or user based in AngloSaxon literature, remixibility and reversibility, the participant of an expressive paradigm in which the Internet is both observer and architect" (Allard, 2007, p. 21).

Thus, the blogs, which began in the form of journals, made each blogger an independent journalist with the help of technology, many becoming well-known writers. There is a "cultural convergence" (Jenkins, 2006) by spreading the same message across multiple virtual platforms. Most writers started writing on the blog, mostly of diary type, where they created communities that they transferred to social networks. Each author who owns a blog has, in addition to its personal Facebook profile, a blog page, which in its turn has pages on Instagram, Linked In, or Twitter. Each user uses a certain identity in creating online connections. Bouvier (2012) states that "the regime of an identity is given by three factors: the country of origin, the lifestyle and the cultural or ethnic identity" (p. 41). In the case of writers, the latest research has shown that pieces of everyday life displayed on Facebook have a more significant impact than posting cultural products (Wiart, 2017, p. 352). The writers have built their notoriety by exposing themselves, by alternating sequences from personal life with texts with debate and cultural product subjects, either their own or not.

\section{The mediatization of writers by self-exposure with promoting purpose}

The communication on social networks is performed through micro-narratives by users, who also become content creators. The dependency created by the digital is associated with the story dependency: "The psychic projection on the desired screen of the character allows the reader to make its inner cinema and create its fantasies, without this instinctual discharge being compromised or socially risky. We are approaching what Aristotle theorized as catharsis" (Migozzi, 2010).

The writers who are the subject of our study have a double identity in this case, once through the status of a publicly recognized writer, the one who writes and offers stories through its books, and the identity of a narrator on the internet to interact with the readers. The writer's 
legitimacy gives an advantage from the start, the public receives its stories on social networks or blogs with a guarantee certificate. The writers become similar to the celebrities in other industries, the messengers of stories in which readers can find themselves or motivate them in their actions.

The micro-narratives on social media can be compared to television series consisting of episodes that fragment everyday life and the viewers find themselves. The "digital texture has replaced the "texture" offered by television." Because we have already mentioned that the digital environment has developed on the practices exercised by traditional media, we may have thus an explanation for the dependency that social media creates through the micro-narratives in the posts. The concept of remediation explains how a story is taken over from one media form to another and carried on (Bolter \& Grusin, 1999). Each medium takes on a story giving it a new form, the storytelling becoming part of digital content.

The posts on social networks are independent, in the sense that they contain an idea, a message, they are pieces of an event that, associated with other fragments, can establish micronarratives.

Turner (1996) defines «small stories of events in space» (Turner, 1996, p. 13) as protonarratives, such as the basic unit which could represent an event (Venditti, Pirreda, Mattana, 2017, p. 276).

From the author's interaction with the readers of the posts, the stories' continuations can appear by combining fragments called "proto-narratives." The one who generates a post through self-exposure challenges others to expose themselves. "On social networks on the Internet, selfexposure is, therefore, the main relational technique" (Cardon, 2011, p. 142). A simple photo with a loaf of bread, for example, posted by a writer during the quarantine period at the beginning of the year 2020, accompanied by a subtle confession (not in the first person) premiere for the author, generated divergent narratives from readers. The discussions had diversified, leading to the yeast crisis and yeast cake bread recipes or recalling moments associated with making bread. The comments made references to video links or recipe blogs, and the participants to the discussion also posted the bread they made. The bread was not a simple photograph and a story, but an element with multiple symbols, a combination of narrative and semiotics. The succession of proto-narratives with the bread has led to the formation of an entire social picture through the 
interaction with the readers, that of a community making bread in quarantine according to various recipes.

Thus, the combined micro-narratives created a social picture of a historical period. Of course, the writer's identity mattered a lot, readers being invited online to share the story of the bread made for the first time and in quarantine conditions. The quarantine period is the story they were all in, and the baking of the bread was a life sequence in which many found themselves.

With the pressure of the pandemic restrictions, the status of the posts has changed, and the narratives have diversified according to the information provided by the media. Specifically, the narratives followed the mainstream news chart, such as the lack of yeast in the stores.

"Self-mediation is a textual process par excellence. In representing ordinary voice through media technologies, it inevitably employs configurations of semiotic systems, from language to image (still or moving) to sound, in new technologized or hyper-mediated textualities that change both the genres of public communication and our modes of engagement with them" (Chouliaraki, 2010, p. 229).

\section{The mediatization of writers during the quarantine between March and April 2020}

We had monitored the activity on Facebook of ten contemporary Romanian writers (five women and five men) since the moment when the state of emergency was established by military ordinance, more precisely the week of 23-29 March and 13-20 April, which also included the Easter holidays. Accordingly, we aimed at creating a chart on the status of posts and narratives used in the interaction with Facebook users a few weeks away. We used the self-ethnography method of online journal type, the content analysis, ACC, and non-participatory observation. The writers' selection criteria were: the ranking of book sales, notoriety, and online activity.

\section{The week of 23-29 March 2020 (total 120 posts)}

COVID-19 and book promotion posts have a share and are the main points of interest for active online writers. The most used medium is a video in book promotion-just one selfie. Posts about COVID-19 are primarily personal, in the form of opinions or reasons to interact with followers. 


\section{Figure 1}

Types of posts (23-29 March 2020)

\section{Types of posts 23-29 March 2020}

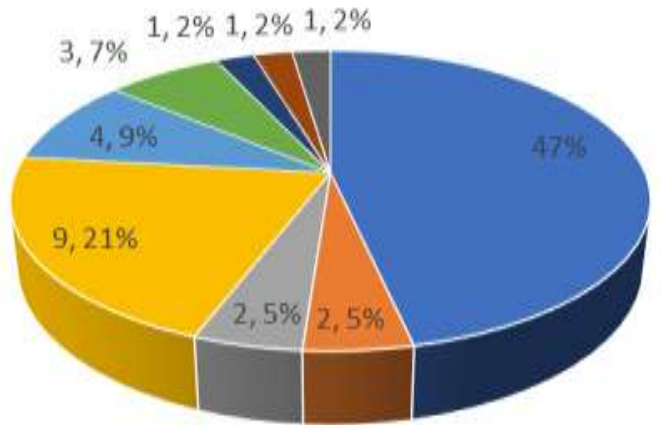

$$
\begin{aligned}
& \text { - Pandemic }=\text { Storytelling } \text { " Art blog } \text { " Book Promo }=\text { Photo } \\
& \text { "Video } \quad \text { - Politic } \quad \text { - Selfie }
\end{aligned}
$$

We also identified the status of those who posted that week. Nostalgic and sad posts predominate, followed by those ironic/funny, and then it follows fear, solidarity, and optimism.

\section{Figure 2}

Types of narratives used in the interaction with Facebook users (23-29 March 2020)

\section{Types of narratives 23-29 March 2020}
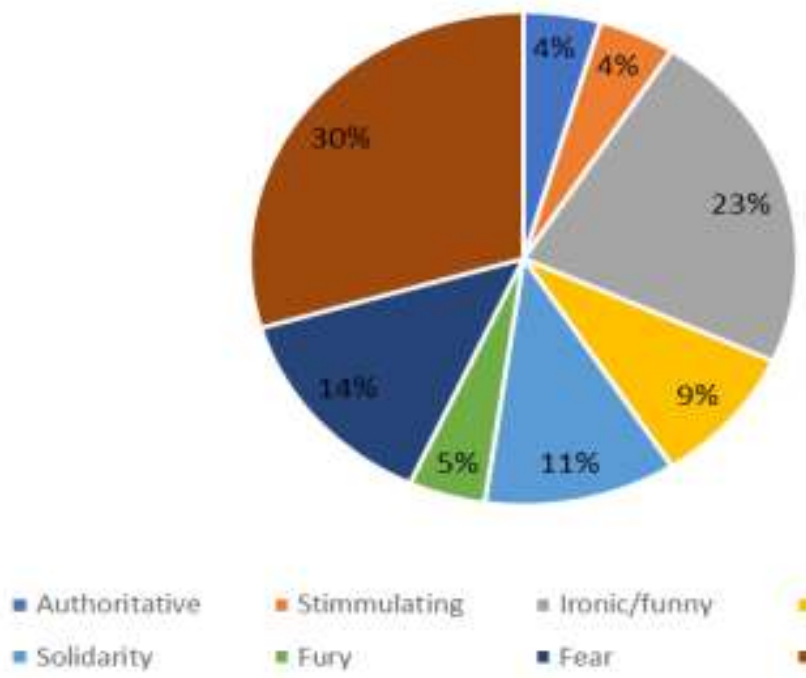

= Ironic/funny

= Optimism

" Solidanity

= Fury

- Fear

- Nostalgia/Sadness 


\section{The week of 13-20 April 2020 (104 posts)}

For the week of 13-20 April, we found that since the last monitoring (23-29 March), the narrative in the posts on the topic of COVID-19 has diversified, and we have found 12 topics in the posts on the pandemic: 1. Medical, 2. Economic, 3. Relationships, 4. Political, 5. Religious, 6. Cultural, 7. Self-exposure, 8. Psychological, 9. Language, 10. Social distance, 11. Isolation, 12. Easter. This way, we could more easily identify which were the favorite topics in the stated context.

We have performed an analysis of the entire period of 13-20 April, cumulating the narratives on COVID-19 topic and the other types of narratives.

Out of the total of 51 posts on COVID-19, most of them were on Easter, isolation, and religion.

\section{Figure 3}

Types of pandemic narratives used in the interaction with Facebook users (13-20 April 2020)

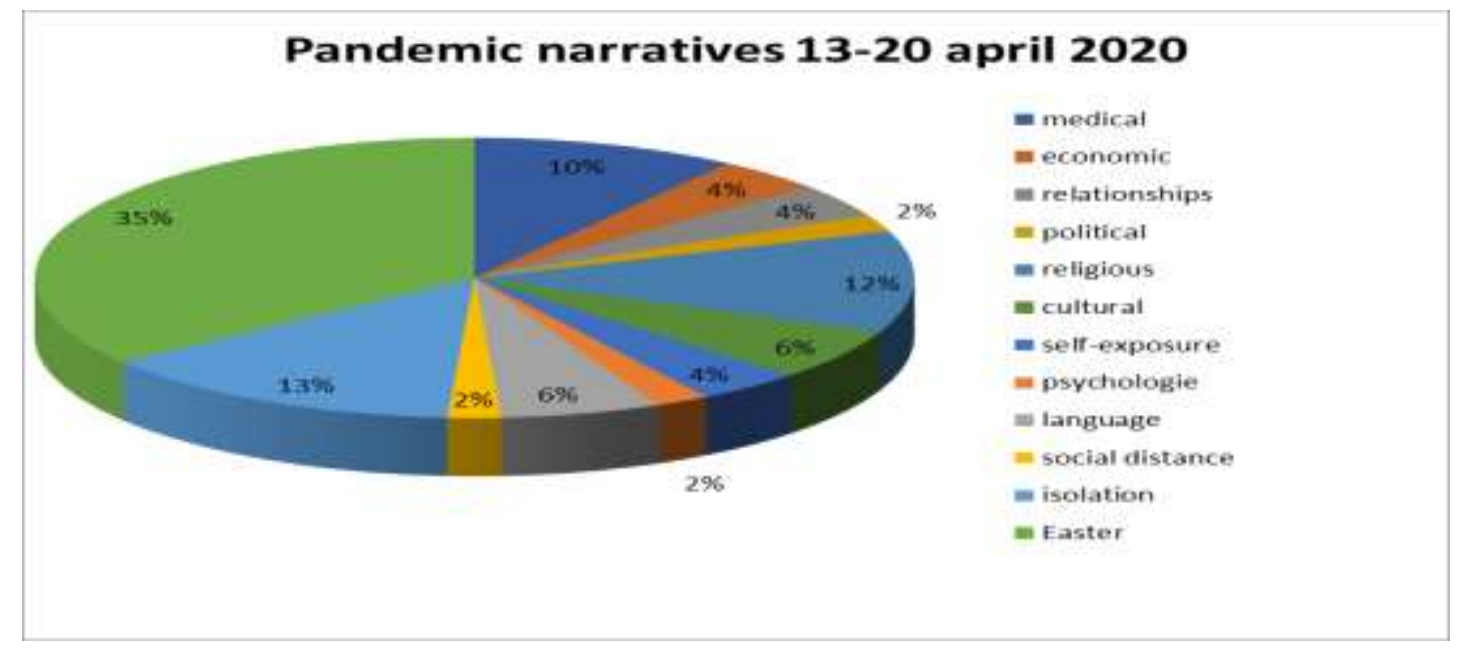

We have also monitored the narratives other than those on COVID-19. Out of the 86 posts, the most common are: cultural / book promotion, blog posts, and storytelling. The favorite media are photo and video, especially for cultural and reading promotions. We also included here the posts on video and photo media because they have content that is the study's object, and the narration is different from the content of the posts, some being multimodal: photo and text, or text and video. Another proof of how the authors mediatize themselves use social network tools to promote themselves, using various media and communication devices. 


\section{Figure 4}

Types of post narratives used in the interaction with Facebook users (13-20 April 2020)

\section{Type of post narrative 13-20 april 2020}

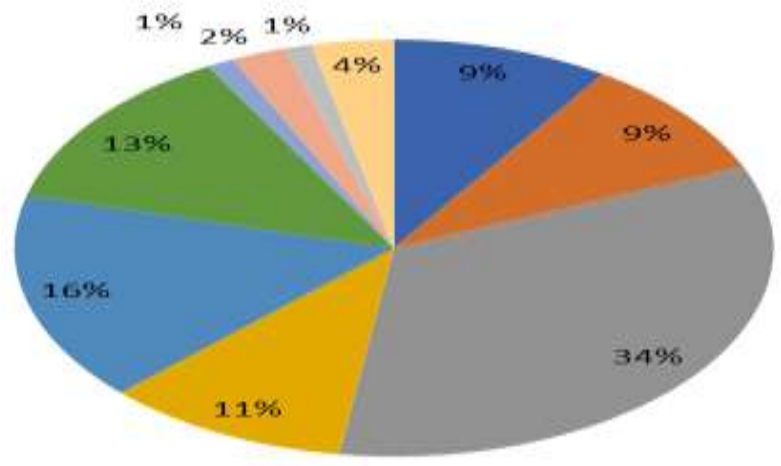

$$
\begin{aligned}
& \text { = Storytelling } \\
& \text { = Blog article } \\
& \text { = Cultural/Book promotion } \\
& \text { = community } \\
& \text { = Photo } \\
& =\text { Video } \\
& =\text { Selfie } \\
& =\text { Sport } \\
& =\text { Political } \\
& =\text { Recipes }
\end{aligned}
$$

During this period, the authors' mood was of amusement, alternating with nostalgia and sadness, due to the Easter holidays. Optimism and solidarity are among the strongest of the other types of moods. We can also talk about mediatization here, the posts' status following the mainstream media's chart.

\section{Figure 5}

Types of post status used in the interaction with Facebook users (13-20 April 2020)

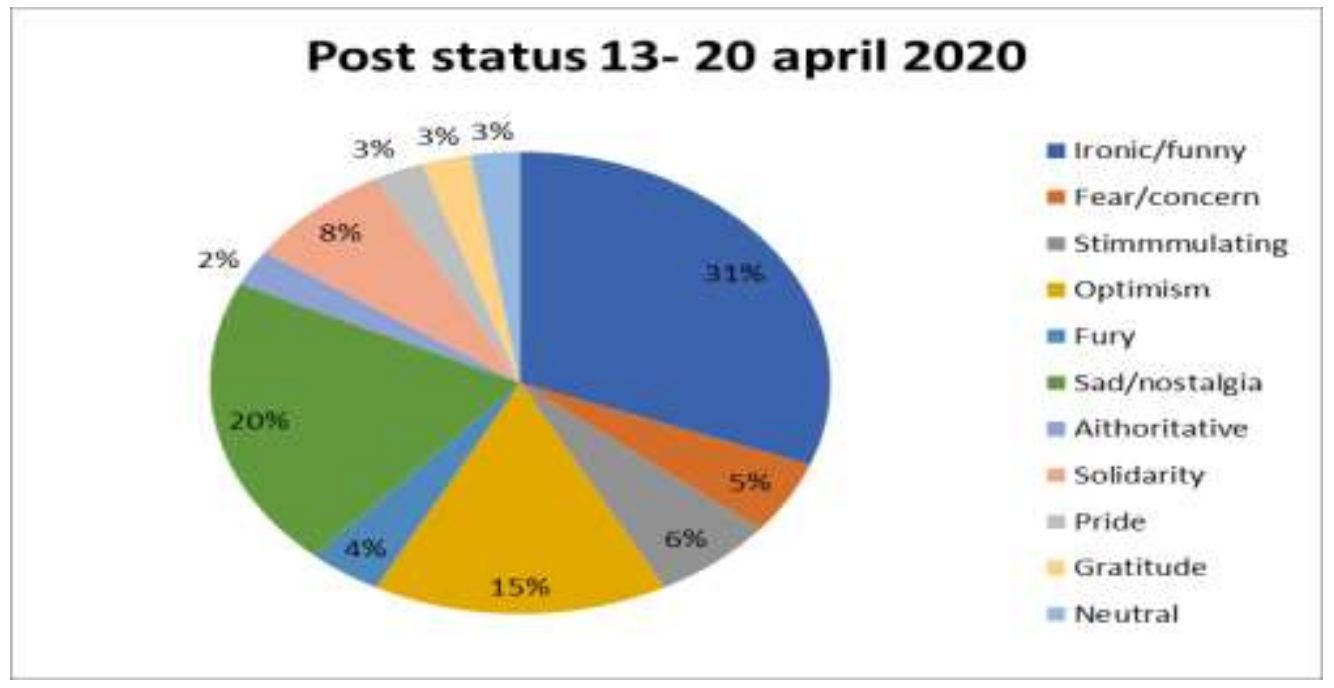

The predominant identity is that of the writer, followed by that of the blogger. In the days before Easter, the identity of a child appears. 


\section{Figure 6a}

Types of identities used in the interaction with Facebook users (13-16 April 2020)

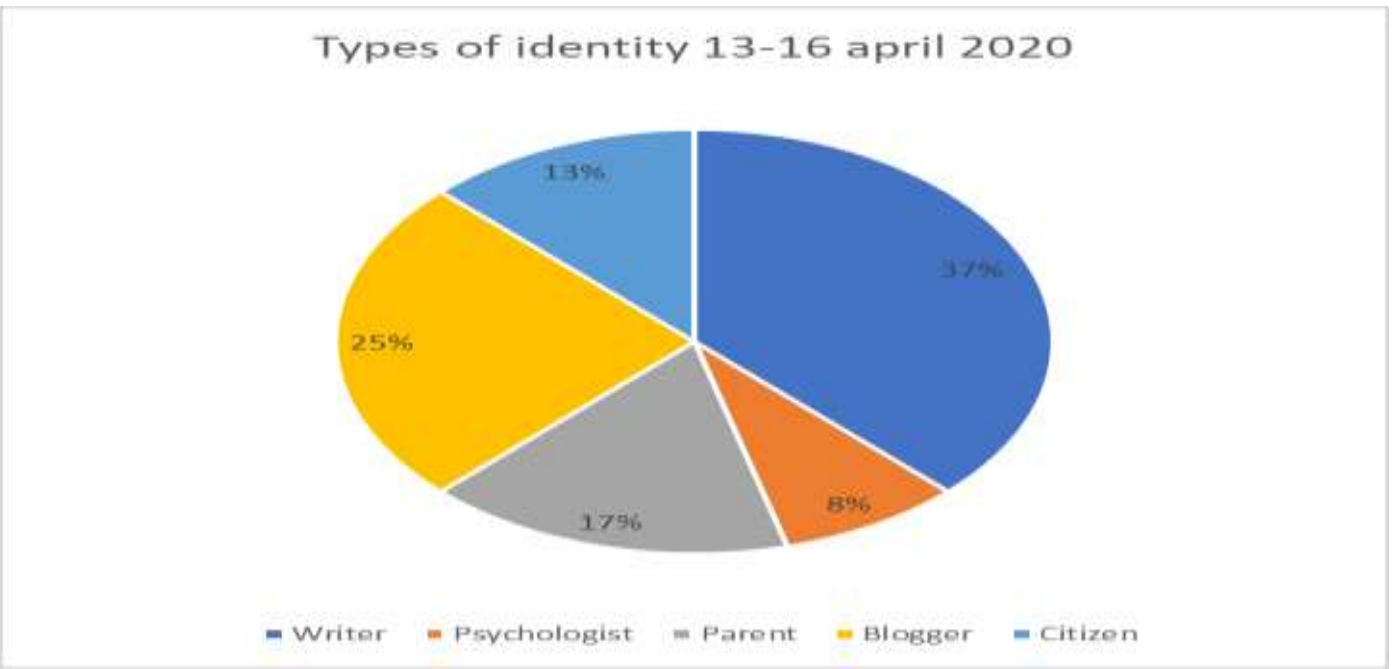

\section{Figure 6b}

Types of identities used in the interaction with Facebook users (17-20 April 2020)

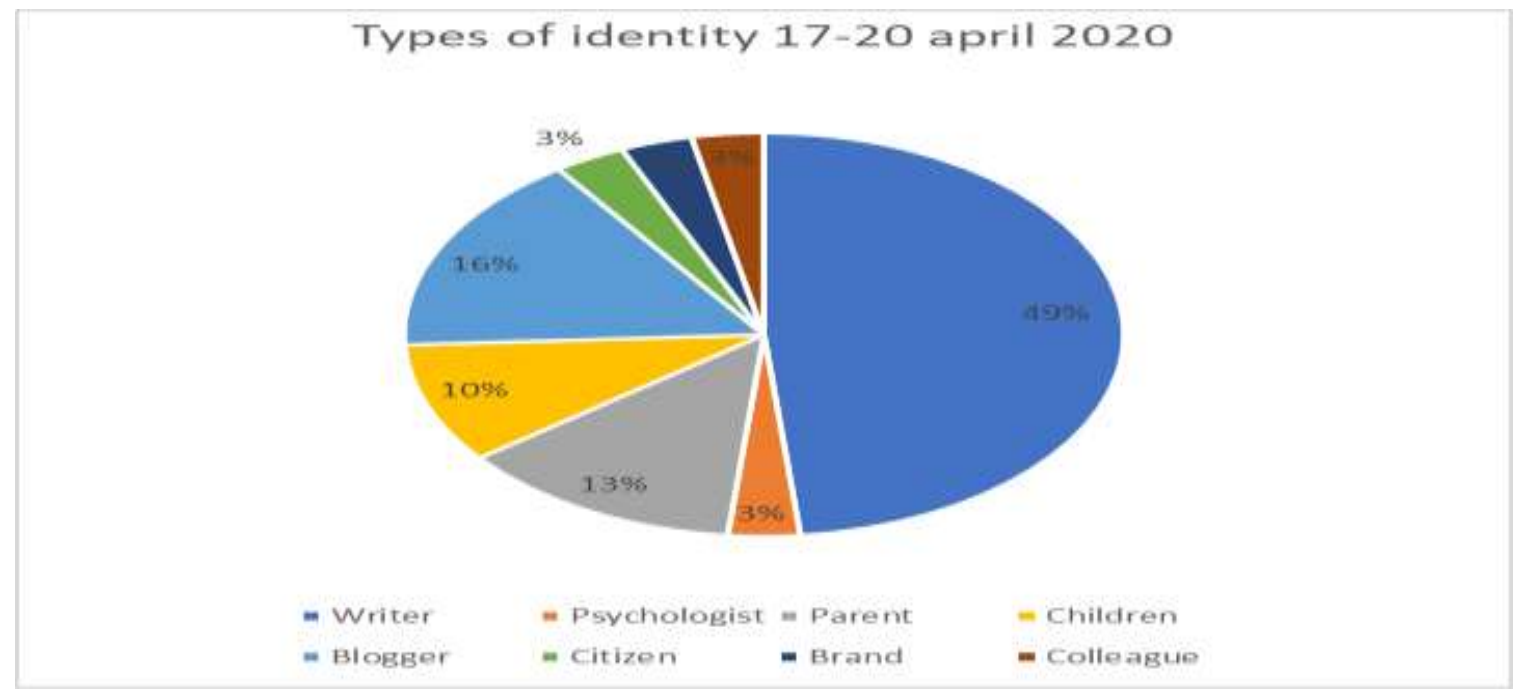

\section{Conclusions}

Cultural promotions are most numerous online, which shows an attempt to maintain the balance during this period, namely preserving the identity of the writer and blogger during the isolation period, including Easter. The narratives addressed on the pandemic are about Easter, isolation, and religion, an order that demonstrates this effort to maintain the landmarks in the transmission of messages and the communication with readers. The fact that the states of the 
posts alternate to the same extent from amusement to sadness and nostalgia is nothing but the revelation of the authors' identities in online communication: writer, blogger, and parent. The increase of posts using storytelling can be interpreted as an emerging writer-blogger-parent identity and multiple identities due to Easter isolation. Hope, optimism, and the desire for civic involvement are reflected in the citizen's identity, which appears in the posts.

To follow the mood of the posts around the Easter holidays, we took into account the week before and the days after the night of the Resurrection, which had been spent in isolation during the pandemic. The most debated topics were those about the measures taken by the authorities for the night of the Resurrection and the controversies over how to bring the "light": by Police, BOR (The Romanian Orthodox Church) representatives, parishioners, then it remained in the responsibility of BOR. This news had been taken over on Facebook by the writers and treated with humor, through self-mediatization, accumulating several identities: citizen/elector/supporter of a policy, intellectual, and influencer. This explains the mix of posts with nostalgic moods that alternate with happy ones. During the mentioned period, the writers had mediatized themselves following the news programs' chart from the mainstream media but related to their own identity and purposes in their activity on social networks.

\section{References}

Allard, L. (2007). Émergence des cultures expressives, d'internet au mobile [Emergence of expressive culture, from internet to mobile]. Mediamorphoses. http://hdl.handle.net/2042/23558

Bolter, D. J., and Grusin, R. (1999). Remediation: understanding new media. MIT Press. Bouvier, G. (2012). How Facebook users select identity categories for self-presentation. Journal of Multicultural Discourses, 7(1), 37-57. 10.1080/17447143.2011.652781

Cardon, D., \& Delaunay-Teterel, H. (2006). La production de soi comme technique relationnelle [Self-production as a relational technique]. Lavoisier|Réseaux, 24(138), 15-71. https://www.cairn.info/revue-reseaux1-2006-4-page-15.htm

Cardon, D. (2008). Le design de la visibilité. Un essai de cartographie du web 2.0. [The design of visibility. A web 2.0 mapping essay]. Réseaux 6(152), 93-137. https://doi.org/10.3166/reseaux.152.93-137

Cardon, D. (2011). Réseaux sociaux de l'Internet [Social network of internet]. Communications, 
141-148. https://www.cairn.info/revue-communications-2011-1-page-141.htm

Castells, M. (2009). Communication power. OUP Oxford.

Chouliaraki, L. (2010). Self-mediation: new media and citizenship. Critical Discourse Studies 7(4), 227-232. https://doi.org/10.1080/17405904.2010.511824

Deacon, D., \& Stanyer, J. (2014). Mediatization: key concept or conceptual bandwagon? Media, Culture \& Society, 36(7), 1032-1044. https://doi.org/10.1177/0163443714542218

Driessens, O. (2013). The celebritization of society and culture: Understanding the structural dynamics of celebrity culture. International Journal of Cultural Studies, 16(6), 641-657. https://doi.org/10.1177/1367877912459140

Eliade, M. (1978). Aspecte ale mitului [Aspect of the myth]. Bucharest University Publishing House.

Esser, F., Strömbäck, J. (2014). Mediatization of Politics: Toward a Theoretical Framework. In F. Esser \& J. Strömbäck (Eds.), Mediatization of Politics Understanding the Transformation of Western Democracies (pp. 3-28). Palgrave MacMillan.

Fiske, J. (2013). Cultural studies and the culture of everyday life. Cultural Studies, 154-173. https://doi.org/10.4324/9780203699140

Goffman, E. (1967). Interaction ritual-essays face-on-face behavior. New York : Anchor Books.

Goffman, E. (2007). Viața cotidiană ca spectacol [The Presentation of Self in Everyday Life]. Comunicare.ro Publishing House, Bucharest.

Granjon, F., \& Denouël, J. (2010). Exposition de soi et reconnaissance de singularités subjectives sur les sites de réseaux sociaux. [Self-exposure and recognition of subjective singularities on social networking sites]. Presses Universitaires de France | Sociologie, 1, 25-43. https://www.cairn.info/revue-sociologie-2010-1-page-25.htm

Hidri, A., \& Smati, N. (2013). Le self media et l'exploration du moi [The Self Media and exploration of self]. Open Edition Journal, 31(2).

https://doi.org/10.4000/communication.4510

Holmes, S. (2005). Starring... Dyer?: Re-visiting Star Studies and Contemporary Celebrity Culture. Research Gate. https://doi.org/10.16997/wpcc.18

Jenkins, H. (2006). Convergence Culture. Where Old and New Media Collide, New York University Press. 
Marshall, D. P. (2010). The promotion and presentation of the self: celebrity as a marker of presentational media. Journal Celebrities Study, 1, 35-48. https://doi.org/10.1080/19392390903519057

Migozzi, J. (2010). Storytelling: opium du peuple et / ou plaisirs du texte? [Storytelling: popular opium and/or textual pleasures?], French Cultural Studies 1(4), 247-255. https://doi.org/10.1177/0957155810378567

Miller, R. C., \& Sheperd, D. (2004). Blogging as social action: A genre analysis of the weblog. Into the Blogosphere: Rhetoric, Community, and Culture of Weblogs. https://conservancy.umn.edu

Peicheva, D. (2006). Beginnings of the mediatization of modern society. The Romanian Review of Journalism and Communication, 1(2-3).

Peicheva, D. (2014). Mediatizarea Societatii DPBG In M. Petcu (Ed), Dictionare enciclopedic de comunicare. Bucuresti Editura CH Beck.

Papacharissi, Z. (2014). Affective publics: Sentiment, Technology, and Politics. Oxford University Press.

Turner, G. (2006). The mass production of celebrity: 'Celetoids', reality TV and the 'demotic turn. SAGE Journal of Cultural Studies, 9(2), 153-165. https://doi.org/10.1177/1367877906064028

Van Aelst, P., Thesen, G., Walgrave, S., Rens, V. (2014). Mediatization and Political Agenda Setting: Changing Issues priority?. In F. Esser\& J. Strömbäck (Eds.), Mediatization of Politics Understanding the Transformation of Western Democracies, (pp. 211-220). Palgrave MacMillan.

Venditti, S., Pirreda F., \& Mattana W. (2017). Micro narratives as the form of contemporary communication. The Design Journal, 20:sup1, S273-S282. https://doi.org/10.1080/14606925.2017.1352804

Wiart L. (2017). La Prescription littéraire en réseaux. Enquête dans l'univers numérique [Literary Prescriprion in Networks. Investigation in the digital world], Villeurbanne, Presses de l'Enssib, coll. Papiers. https://doi.org/10.4000/questionsdecommunication.21601 